\title{
A SEPARABLE AND INSEPARABLE TRANSITIVE PHRASAL VERBS
}

\author{
Diana Anggraeni ${ }^{1}$, Cece Sobarna ${ }^{2}$, Lia Maulia ${ }^{3}$, Eva Tuckyta Sari Sujatna ${ }^{4}$ \\ ${ }^{1}$ English Department, Faculty of Social and Political Sciences Bangka Belitung University \\ 2,3,4Faculty of Cultural Sciences Padjadjaran University
}

Corresponding Author: Diana Anggraeni, E-mail: dianaanggraeniubb@gmail.com

\begin{tabular}{|c|c|}
\hline ARTICLE INFO & ABSTRACT \\
\hline $\begin{array}{l}\text { Received: } 03 / 03 / 2020 \\
\text { Accepted: } 28 / 03 / 2020 \\
\text { Published: } 31 / 03 / 2020 \\
\text { Volume: } 3 \\
\text { Issue: } 1 \\
\text { DOI: } \\
\text { https://doi.org/10.33019/ } \\
\text { berumpun.v2i2.25 } \\
\text { KEYWORDS } \\
\text { Phrasal verbs, separable } \\
\text { transitive, inseparable } \\
\text { transitive, particle, } \\
\text { categories }\end{array}$ & $\begin{array}{l}\text { This research is entitled A Separable and Inseparable Phrasal Verbs. } \\
\text { This research is aimed at identifying and analyzing the forms of } \\
\text { phrasal verbs and their restoration. Greenbaum and Nelson (2002) } \\
\text { syntactic theory to find out the syntactic actions and the distinctive } \\
\text { essence of phrasal verbs. Theories from McCarthy and O'Dell (2004) } \\
\text { and Djajasudarma (2016) are used to evaluate the restoration of } \\
\text { phrasal verb with a single verb and other phrasal verb. The research } \\
\text { method used is a descriptive qualitative method in understanding } \\
\text { photographing data as it is. The distributional method is used to study } \\
\text { the data that has been collected by referring to the method, note } \\
\text { taking and identification techniques then find their meaning based on } \\
\text { a dictionary. The results of phrasal verb research show five types } \\
\text { separable transitive phrasal verb dynamic such as carry through, cut } \\
\text { through, push through, read through, and talk through. While } \\
\text { inseparable transitive phrasal verb dynamic such as break through } \\
\text { 'overcome', breeze through 'accelerate', cut through 'cut through,' } \\
\text { glance through 'flick through' and get through 'contact'. }\end{array}$ \\
\hline
\end{tabular}

\section{INTRODUCTION}

Verbs can be expanded by adding certain elements, but the results of this expansion remain at the same syntactic level. The form of extension of the verb that remains at the same syntactic level is called phrasal verbs. In Indonesian, the term phrasal verbs has not yet been found to be equivalent. Phrasal verbs are verbs followed by adverbial particle. The same opinion is explained by Wyatt (2006: 3) and McCarthy and O'Dell (2007: 6) phrasal verbs are verbs that contain a verb and a particle, such as make up, give in, look after, look up, look up, and pass through.

Phrasal verbs consist of main verbs, usually motion verbs such as go, put, take, and one or more particle. Particle can be adverbs, prepositions, or words that can act both as adverbs and prepositions.

In English, phrasal verbs are expressions that indicate actions - such as turn down or run into. This term applies to two or three different constructs, but is related: verbs and particle and / or prepositions together form a semantic entity. Semantically, phrasal verbs can take the form of concrete actions with concrete meanings and abstract meanings (Mc.Carthy \& O'Dell, 2007:8). For example:

1. I gave my essay in yesterday.

2. Her parents finally gave in and let her go 
Example sentences (1) use the phrasal verb give in with a literal meaning which has the same meaning as the main verb meaning give, while the example sentence (2) uses a given phrasal verb but means a metaphor that is 'surrender' or 'His parents finally gave up and let him go to the party.' because the verb does not have similarity with the main verb.

If noted further, the use of phrasal verb in sentences is not the same. For example, research conducted by Machonis (2009) tested 300 phrasal verbs in English using particle up. According to Machonis (2009), there are phrasal verb that do not have the same meaning without a particle and must be listed in the idiomatic expression lexicon grammar, for example break up the audience which means 'cause of laugh' (making visitors laugh). Machonis's research on verb phrases only added the elemental elements of the main verb, and the use of a particle was analyzed as an element of the main verb. Although this meaning is difficult to characterize, generally phrasal verb means idioms such as showing the direction (ride up the elevator), completion (open up the store), intensity (hype up the book), or a combination (polish up the silverware, completion and intensity). Machonis's research on phrasal verb is a combination of verbs and particles because these two elements have different meanings from their lexical meanings.

Besides the particle up used in the Machonis research above there are many other particles used in the formation of phrasal verbs such as particles: aboard, about, above, across, alongside, around, before, behind, below, beneath, besides, between, beyond, by, down, in, inside, less, near, off, through. This research will focus on the use of particle through in English phrasal verb. There are several issues related to the syntax and semantics of particle through in phrasal verb which attracts the attention of the writer to investigate deeper about the phrasal verb particle through, considering the particle through is one type of particle that is still rarely discussed in English sentences. Phrasal verb particle through has several variations of meaning, as in the example sentences below:

3. I don't think they have really thought the problem through.

'I didn't think they really solved the problem'.

4. I will put you through to Mr. Smith.

'I will connect you to Mr. Smith.'

In sentence (3) the particle through which joins the thought verb (think) forms the phrasal verb think through which means "finish". In this phrasal verb the particle 
https://berumpun.ubb.ac.id/index.php/BRP

through means the completion of an activity from beginning to end. However, in sentence (4) the particle through has a different meaning. The particle through joined by verb put have a connected meaning. In this sentence, particle through has its own privileges because it is only used in telephone communication.

The object of discussion in the phrasal verb particle through is taken from the British National Corpus. This corpus data is used because the data is arranged systematically and easily accessed digitally. This data is used in descriptive and applied linguistics, such as for dictionary compilation. The data used really comes from broad use and avoids subjective use. Corpus data has a wide variety of sentence construction and comes from a variety of data sources both verbally expressed through written language and writings originating from newspapers, magazines, novels, and so on. Study of English phrasal verb has been found quite a lot, but in-depth research on semantic studies and the syntax of phrasal verb particle through has not yet existed. This research will explore the types of phrasal verb particle through and the restoration of phrasal verb particle through in English. A particle through in this research, it is expected that the characteristics of phrasal verb particle through can be seen based on the type of verb and its restoration.

\section{LITERATURE REVIEW}

\section{A. Phrasal Verb}

Phrasal verb is a verb formed from two (or sometimes three) parts: verb and particle or adverbial particle (Klammar, 2000: 401; McCarthy \& O'Dell, 2004: 6; Wyatt, 2006: 1; Lester, 2009: 14; Jackendoff, 2010: 228; Lackman, 2012: 3; Leech and Svartvik, 2013: 243). Particles used in phrasal verb is not prepositions, even though they use the same word, their usage is different. Prepositions are words that syntactically appear before a noun, adjective, or adverb and semantically mark the various meaningful relationships between the constituents in front of and behind the preposition. Conversely, a particle is semantically fused with verbs, and the meaning of verbs can be very different from verbs if they do not have a particle attached to them. The following sentences are examples of the use of particles and prepositions attached to verbs:

5. She walked up the street to get a bite to eat.

6. I live up in Springfield.

7. When are you going to clean up your room?

8. I am sorry that I messed you up.

(Celce-Mursia and Larson Freeman, 2016: 425)

Sentences (5) and (6) are sentences with verbs followed by prepositions up, while sentences (7) and (8) are sentences with verbs followed by particles up. The verb clean in sentence (7) and the verb mess in sentence (8) combined with a particle up is a Phrasal verb.

Most phrasal verbs are formed from the main verb (for example: get, go, come, put and set) and a number of particles (for example: away, out, off, up, through and in). According to Biber (2009: 403) phrasal verb is word complex units consisting of verbs followed by adverbial particles (carry out, find out, pick up). Adverbial particles all have a spatial or locative meaning (out, in, up, down, on, off); However, adverbial particles 
https://berumpun.ubb.ac.id/index.php/BRP

are usually used with expanded meanings. As the following example: You hold something in your hands.

phrasal verb usually represents a single semantic unit that cannot be derived from the individual meaning of the two parts. Therefore, phrasal verbs are often lexical verbs that have similar meanings to word verbs, such as:

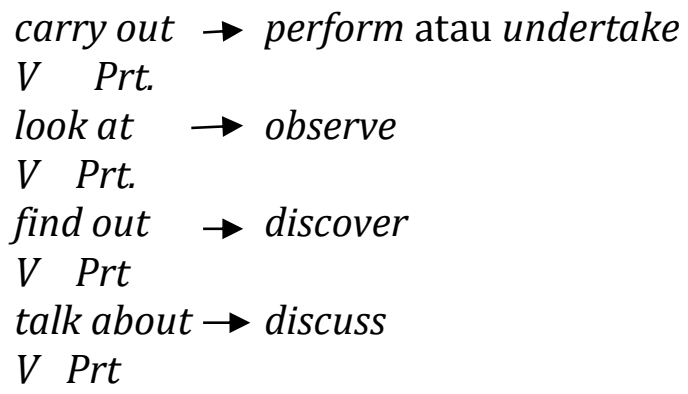

\section{B. Phrasal verb syntax behavior}

Phrasal verb has two behaviors: syntactic and semantic behavior. Syntactic behavior shows that the elements used to form phrasal verbs consist of verb elements plus prepositions that function as adverbial or are called particles. Phrasal verb from a syntactic perspective consists of transitive phrasal verb and intransitive phrasal verb (Biber et.al, 2009: 407; Celce-Murcia, 2016: 426; Lackman, 2012: 3). A transitive phrasal verb is a phrase that can be followed by an object can be noun or pronoun. Some phrasal verbs are separated by objects directly between verbs and particles. If the object is a noun, the phrase can be separated or not. However, if the object is a pronoun (me, you, her, him, it, us, them) the phrase must be separated (Klammar, 2000: 402).

9. I put my shoes on.

10. He had put on his spectacles.

In sentences ( 9 and 10) particles on can be placed before or after the object. A transitive phrasal verb is divided into two, separable phrasal verb and inseparable phrasal verb, which differ in the number of slots in which particle can appear.

\section{a. Separable phrasal verb}

A separable phrasal verb is a verb and particle that can be separated and objects can be placed in the middle between verbs and particle (Lackman, 2012: 3). As the example sentence below:

11. Jerry Stoneham looked up the number in the directory and whistled in Jerry Stoneham, surprise, for it was the same number that he had found in the dead man's diary.

The sentence in example (11) up does not indicate direction or has a special meaning. Conversely, the combination of verb look and up has a special meaning. Although followed by the number noun phrase, up is not a preposition in the sentence 
https://berumpun.ubb.ac.id/index.php/BRP

here. The following example uses a diagnostic test, where up has not been shifted using the wh question noun phrase, the sentence below is very grammatical:

12. What number did Jerry Stoneham look up?

If $u p$ is moved together using the phrase $w h$. The results are not grammatical: 12a. * Up what number did Jerry Stoneham look?

So, the example in sentence (11a) up fails in the diagnostic test for prepositions and is a particle. The verb look and particle up are combined as transitive word complex verbs. The following sentence shows that the look up is a separable phrasal verb: up can be separated from the verb look, and this separation is mandatory if the object is a pronoun:

12 b. Jerry Stoneham looked it up in the directory.

Many transitive phrasal verbs, whether a separable or inseparable, have a single verb. As an example of using phrasal verb which is separate:

$$
\begin{array}{lc}
\text { bring back }=\text { return } & \text { drive out }=\text { expel } \\
\text { bring up }=\text { raise } & \text { give up }=\text { surrender, forsake } \\
\text { call off }=\text { cancel } & \text { leave out }=\text { omit } \\
\text { call over }=\text { summon } & \text { turn down }=\text { refuse } \\
\text { check out }=\text { investigate turn out }=\text { evict }
\end{array}
$$

\section{b. Inseparable phrasal verb}

An inseparable phrasal verb is a verb and particle that cannot be separated, and objects cannot be placed halfway between verbs and particles (Celce-Murcia, 2016: 430). As the example sentence below:

13. Guess what I ran into an old friend last night.

14. Rita will stand by you, Jim. You know that.

Some phrasal verbs have three constituents: ordinary verbs followed by direction and particle adverbs. The verbs below are inseparable phrasal verbs, such as:

cut down on
drop in on
get away with
go back on
go through with
keep up with
look down on
make up for
put up with
run out of

"reduce"
"visit casually"
"violate a rule without punishment"
"violate an agreement"
"finish, complete"
"stay level with"
"despise"
"compensate"
"tolerate"
"have no more




\section{METHOD}

This research is qualitative study. Qualitative research is characterized as a method of market research focusing on data acquisition through open-ended and conversational communication. This approach is not only about "what" people think but also about "why" people think so. Consider, for starters, a convenience store looking to increase its patronage. One systematic observation suggests that there are more men visiting this shop. A good way of evaluating why people did not visit the store is to perform a detailed survey with potential customers in the group.

\section{DISCUSSION}

Transitive phrasal verbs are divided into separable and inseparable transitive phrasal verbs. This form of separation is a syntactic characteristic of transitive phrasal verbs where particle are separated from verbs in the presence of direct objects and particle which are inseparable from the verbs. A form of separation must also be carried out if the direct object that is present is a pronoun.

In an inseparable phrasal verb, the particle present are a form of free morpheme separated from the whole phrasal verb. In an inseparable phrasal verb, the particle that are present cannot normally be free morphemes as the particle in the phrasal verbs are separated because these particle cannot be equated with an inseparable construction.

\section{A. Seperable Transitive phrasal Verbs}

Seperable transitive phrasal verbs are a type of phrasal verb whose particle are separated from the verb and inserted by the noun phrase as its object. In addition, particle must be separated from the verb if the object used is in the form of a pronoun.

Based on the data, fifth separable transitive phrasal verbs were found with through particle, including carry through, cut through, push through, read through, and talk through. Semantically, transitive phrasal verbs are separated into groups of dynamic verbs.

\section{Carry through}

The phrasal verb carry through belongs to the type of transitive verb because it requires an object. Syntactically, the transparency of the phrasal verbs in the sentence below can be observed through the construction of the sentence as follows:

3. The songs of the whales carry through the water. 
https://berumpun.ubb.ac.id/index.php/BRP

4. He says that Speywood did not carry through the business.

Based on the above construction, the noun phrase the water and the business are present as direct objects for the phrasal verbs carry through. Seen from its construction, phrasal verbs carry through verbs are transitive phrasal verbs consisting of verb carry and particle through. Based on the separability of phrasal verbs, carry through is separated between verbs and particle. This can be proven by syntactically testing as below:

Conversion to a passive form:

3. The songs of the whales carry through the water.

'Whale songs carry water.'

4. He says that Speywood did not carry through the business.

'He said that Speywood did not run business plan. '

Changed to a passive sentence to:

3a. The water is carried through the songs of the whales.

'Water is carried by whale songs.'

4a. He says that the business was not carried through by Speywood.

'He said that his business was run by Speywood. '

Sentence patterns ( 3 and 4) experience a change to passive form as indicated by sentences ( $3 a$ and $4 a$ ). This can only be done if the phrasal verb is composed of verbs and particle. Based on testing in the passive form, the word through in the phrasal verb carry through is a particle form.

Insertion of noun phrases

3. The songs of the whales carry through the water

'Whale songs carry water.'

4. He says that Speywood did not carry through the business.

'He said that Speywood did not run the business. '

The noun phrase is inserted between the verb and the particle to be:

$3 \mathrm{~b}$. The songs of the whales carry the water through

'Whale songs carry water.'

4b. He says that Speywood did not carry the business through.

'He said that Speywood did not run the business.'

The insertion of noun phrases the water and the business in sentence construction ( $3 \mathrm{~b}$ and $4 \mathrm{~b}$ ) does not change the meaning of the sentence so that the word through in that sentence can be expressed as a particle for verb carry.

Semantically, the phrasal verb carry through in sentences (3) and (4) is a dynamic verb of the type of activity verb. As it functions, activity verbs indicate actions and events with subjects acting as agents in a semantic way. In sentence (3) the subject of the songs of the whales acts as an agent because this subject carries out the activity of 'carrying'. 
https://berumpun.ubb.ac.id/index.php/BRP

In sentence (4) the subject Speywood acts as an agent for the phrasal verb carry through.

\section{Cut through}

The transitive phrasal verb in the sentence below can be observed syntactically through the sentence construction as follows:

5. Gerald Smith cut through red tape.

The red tape noun phrase based on the above construction, is present as a direct object for the phrasal verbs cut through.

Seen from its construction, the phrasal verbs cut through is a transitive phrasal verb consisting of verb cut and particle through. Based on the nature of the separability of phrasal verbs, the phrasal verbs cut through are separated between verbs and their particle. This can be proven by syntactically testing as below:

Conversion to a passive form:

5. Gerald Smith cut through red tape.

'Gerald Smith accelerates bureaucracy.'

Changed to a passive sentence to:

5a. Red tape is cut through by Gerald Smith.

'Bureaucracy is accelerated by Gerald Smith.'

The sentence pattern (5) changes to a passive form as shown by sentence (5a). This can only be done if the phrasal verb is composed of verbs and particle. Based on testing in the passive form, the word through in the phrasal verb cut through is a particle form.

Insertion of noun phrases

5a. Gerald Smith cut through red tape.

'Gerald Smith accelerates bureaucracy.'

The noun phrase is inserted between the verb and the particle to be:

5b. Gerald Smith cut red tape through.

'Gerald Smith accelerates bureaucracy.'

The insertion of noun phrase the red tape in sentence construction (5b) does not change the meaning of the sentence so that the word through in that sentence can be expressed as a particle

for the verb cut.

The phrasal verb cut through in sentence (5) includes dynamic verbs that are types of activity verbs. This verb shows actions and events with subjects acting as 
https://berumpun.ubb.ac.id/index.php/BRP

agents semantically. In sentence (5), Gerald Smith acts as an agent that engages in 'accelerating' activities.

\section{Push through}

Syntactically, the transitive phrasal verb push through in the sentence below can be observed through the sentence construction as follows:

6. United manager Keegan could push through a 750,000.

7. True haustorial cells push through the prehaustorial cells.

Seen from its construction, the phrasal verb push through is a transitive phrasal verb consisting of verb push verbs and particle through. Due to the separability of the phrasal verbs, the phrasal verbs push through can be separated between the verbs and the particle.

This can be proven by syntactically testing as below:

Conversion to a passive form:

6. United manager Keegan could push through a 750,000.

'United Keegan's manager can break the 750,000 mark.'

7. True haustorial cells push through the prehaustorial cells.

'True haustorial cells stimulate preaporial cells.'

Changed to a passive sentence to:

6a. A 750,000 could be pushed through by United manager Keegan. '750,000 numbers can be broken by United Keegan's manager.'

7a. The prehaustorial cells are pushed through by true haustorial cells.

'Preaporial cells are stimulated by true haustorial cells. '

Sentence patterns (6 and 7). undergoes a change to a passive form as indicated by the sentence ( $6 a$ and $7 a$ ). This can only be done if the phrasal verb is composed of verbs and particle. Based on testing in the form of passive, verb push, the word through is a particle form.

Insertion of noun phrases

6. United manager Keegan could push through a 750,000.

'United Keegan's manager can break the 750,000 mark.'

7. True haustorial cells push through the prehaustorial cells.

'True haustorial cells stimulate preaporial cells.'

The noun phrase is inserted between the verb and the particle to be:

6b. United manager Keegan could push a 750,000 through.

'United Keegan's manager can break the 750,000 mark.'

7b. True haustorial cells push the prehaustorial cells through.

'True haustorial cells stimulate preaporial cells.'

The insertion of the 750,000 noun phrase and the prehaustorial cells in sentence construction ( $6 \mathrm{~b}$ and $7 \mathrm{~b}$ ) verb push does not change the meaning of the sentence so that the word through in that sentence can be expressed as a particle. 
The push through in sentences (6) and (7) are dynamic verbs of the type of activity verb. This verb shows actions and events with subjects acting as agents semantically. In sentence (6), United manager Keegan is the agent, while in a sentence (7) the agent's role is owned by True haustorial cells, both of which carry out activities in the sentence.

\section{Read through}

Syntactically, the transparency of the phrasal verb in the sentence below can be observed through the construction of the sentence as follows:

8. I always read through my essay before handing them in.

Based on the above construction, the pronoun my essay before handing them in comes as a direct object that can be inserted between the verb read and particle through. Judging from its construction, the phrasal verb read through is a transitive phrasal verb consisting of verb read and particle through. Based on the separability of phrasal verbs, the read through is separated between verbs and particle. This looks like data (8) and can be proven again by testing syntactically as below

Conversion to a passive form:

8. I always read through my essay before handing them in.

'I always read my essay before submitting it.'

Changed to a passive sentence to:

8a. My essay is always read through by me before handing them in.

'My essay is always read by me before handing it in. '

The sentence pattern (8) changes into a passive form as shown by sentence (8a). This can only be done if the phrasal verb is composed of verbs and particle. Based on testing in the passive form, the word through in the phrasal verb read through is a particle form.

Insertion of noun phrases

8. I always read through my essays before handing them in.

'I always read my essay before submitting it.'

The noun phrase is inserted between the verb and the particle to be:

$8 \mathrm{~b}$. I always read my essay through before handing them in.

'I always read my essay before submitting it.'

The insertion of the noun phrase my essay before handing them in in the construction of the sentence $(8 \mathrm{~b})$ verbs read does not change the meaning of the sentence so that the word through in the sentence can be expressed as a particle.

Phrasal verbs read through in sentence (8) belong to the group of stative verbs that are mental verbs. This verb indicates activity and mental state and does not 
https://berumpun.ubb.ac.id/index.php/BRP

involve physical actions. In sentence (8), the phrasal verb read through is a verb with a mental activity that has a dynamic meaning.

\section{Talk through}

Syntactically, the phrasal verb talk through in the sentence below can be observed through the sentence construction as follows:

9. They would talk through the case history together.

Based on the above construction, the noun phrase the case history together comes as a direct object for the word through.

Transitive phrasal verbs consisting of verb talk and particle through. Based on the separability of the phrasal verbs, the talk through can be separated between the verbs and the particle. This can be proven by syntactically testing as below:

Conversion to a passive form:

9. They would talk through the case history together.

'They will discuss the history of the case together.'

Changed to a passive sentence to:

9a. The case history together would be talked through by them.

'The history of this case will be discussed together by them.'

The sentence pattern (9) changes into a passive form as shown by sentence (9a). This can only be done if the phrasal verb is composed of verbs and particle. Based on testing in the passive form, the word through in the phrasal verbs talk through is a particle form.

\section{Insertion of noun phrases}

9. They would talk through the case history together.

'They will discuss the history of the case together.'

The noun phrase is inserted between the verb and the particle to be:

$9 \mathrm{~b}$. They would talk the case history through together.

'They will discuss the history of the case together.'

The insertion of the noun phrase the case history together in sentence construction (9b) does not change the meaning of the sentence so that the word through in that sentence can be expressed as a particle for the verb talk.

The phrasal verbs talk through in sentence (9b) belongs to a dynamic group of activity verbs. This verb shows actions and events with subjects acting as agents semantically. In sentence (9), their pronouns act as agents that engage in 'discussing' activities.

Based on its syntactic behavior, the construction of dynamic separable transitive phrasal verbs can be assessed as follows: 


$\mathrm{S}+\mathrm{V}\left\{\begin{array}{c}\text { carry } \\ \text { cut } \\ \text { push } \\ \text { read } \\ \text { talk }\end{array}\right\}$ particle + O (FN)

\section{B. Inseparable Transitive Phrasal Verbs}

Inseparable transitive phrasal verbs are phrasal verbs that have a direct object but the particle are inseparable from the verb. In the following discussion, inseparable transitive phrasal verbs are dynamic. Dynamic inseparable transitive phrasal verbs are inseparable indicating the existence of an activity carried out by the subject of the sentence.

Dynamic inseparable phrasal verbs based on data found fifth activity verbs include, phrasal verbs break through 'overcome', breeze through 'accelerate', cut through 'cut through,' glance through 'flick through' and get through 'contact'. Dynamic inseparable transitive phrasal verbs are inseparably classified as activity verbs.

\section{Break through}

The phrasal verb break through 'overcome' in the following sentence (10) is a type of transitive phrasal verb. This phrasal verb is followed by a direct object in the form of the noun phrase guilt barrier. Syntactically the sentence patterns below can be described as follows:

10. Mothers break through guilt barrier.

Judging from its type, the phrasal verbs break through is an inseparable transitive phrasal verb. This can be proven from testing the following phrasal verbs:

Insertion of noun phrases

In the type of inseparable phrasal verb, the noun phrase which is the direct object of the phrasal verb cannot be inserted between the verb and its particle. This is seen in the following sentence construction:

10. Mothers break through guilt barrier.

'Mothers overcome guilt.'

10a. * Mothers break guilt barrier through.

* 'Mother overcomes guilt through.'

Sentence (10a) shows that the verb break is a type of intransitive verb that cannot be followed by a direct object in the form of noun phrases. Therefore, the phrasal verbs 
https://berumpun.ubb.ac.id/index.php/BRP

break through is inseparable with the insertion of noun phrases between the verb break and the particle through.

\section{Restoration with pronouns}

Tests by restoring noun phrases with pronouns prove that a phrasal verb is inseparable. In this test noun phrases that function as objects are immediately replaced by pronouns of similar objects and placed at the end of sentences.

In sentence (10), the noun phrase guilt barrier that functions as a direct object for the phrasal verb break through is replaced by the pronoun it, becoming:

10. Mothers break through guilt barrier.

'Mothers overcome guilt.'

10a. Mothers break through it.

'Mothers overcome guilt.'

The sentence construction (10b) can be grammatically accepted because the pronoun can replace the direct object of the noun phrase guilt barrier. This proves that the break through phrasal verb is an inseparable phrasal verb.

The verb break, phrasal verbs break through in sentence (10) belongs to a group of dynamic verbs of activity verbs. This verb shows actions and events with subjects acting as agents; 'overcome' activities.

\section{Breeze through}

Syntactically, the sentence below has the following structure:

11. You can breeze through this game.

Based on its syntactic structure, sentence (11) has a phrasal verb in the form of breeze through which is followed by an object in the form of the noun phrase this game. As the characteristics of English verbs in general, the phrasal verb breeze through a form in the sentence above is a transitive phrasal verb because it has a direct object that follows it.

Based on its type, phrasal verbs breeze through are categorized into inseparable transitive phrasal verbs. This is proven by the following tests:

\section{Insertion of noun phrases}

In the type of inseparable phrasal verb, the noun phrase which is the direct object of the phrasal verb cannot be inserted between the verb and the particle. This is seen in the following sentence construction:

11. You can breeze through this game.

'You can accelerate this game.'

11a. *You can breeze this game through. 
* 'You can accelerate this game through.'

Sentence (11a) shows that the verb breeze is a type of intransitive verb that cannot be followed by direct objects in the form of noun phrases. Therefore, phrasal verbs breeze through are inseparable from the insertion of noun phrases between breeze verbs and through particle.

\section{Restoration with pronouns}

Tests by restoring noun phrases with pronouns prove that a phrasal verb is inseparable. In this test noun phrases that function as objects are immediately replaced by pronouns of similar objects and put them at the end of sentences.

In sentence (11), the game's noun phrase that functions as a direct object for the phrasal verbs breeze through is replaced by the pronoun it, becoming:

11. You can breeze through this game.

'You can accelerate this game.'

11b. You can breeze through it.

'You can accelerate this game.'

The sentence construction (11b) can be grammatically accepted because the pronoun can replace the direct object of the noun phrase this game. This proves that phrasal verbs breeze through is inseparable phrasal verbs.

The phrasal verb breeze through in sentence (11) belongs to a dynamic group of activity verbs. This verb shows actions and events with subjects acting as agents semantically. In sentence (11), your pronoun acts as an agent that engages in 'accelerate' activities.

\section{Cut through}

Phrasal verb cut through in sentence (12) is a type of transitive phrasal verb. This phrasal verb is followed by a direct object in the form of the noun phrase and an 11,000volt electricity cable. Syntactically the sentence patterns below can be described as follows:

12. A farmhand was killed when his chainsaw cut through

Judging from its type, the phrasal verb cut through is an inseparable type of transitive phrasal verbs. This can be proven from testing the following phrasal verbs: Insertion of noun phrases

In the type of inseparable phrasal verb, the noun phrase which is the direct object of the phrasal verb cannot be inserted between the verb and the particle. This is seen in the following sentence construction: 
12. A farmhand was killed when his chainsaw cut through an 11,000-volt electricity cable.

12a. * A farmhand was killed when his chainsaw cut an 11,000-volt electricity cable through.

Sentence (12a) shows that the phrasal verb cut through is inseparable by its noun phrase because the insertion of noun phrases in this verb produces a meaning that is not acceptable structurally in English sentences. Therefore, the phrasal verb cut through is inseparable with the insertion of noun phrases between the verb cut and the particle through.

\section{Restoration with pronouns}

Tests by restoring noun phrases with pronouns prove that a phrasal verb is inseparable. In this test noun phrases that function as objects are immediately replaced by pronouns of similar objects and placed at the end of sentences.

In sentence (12), the noun phrase is 11,000 -volt electricity cable. which functions as a direct object for the phrasal verb cut through is replaced by the pronoun it becomes:

12. A farmhand was killed when his chainsaw cut through an 11,000-volt electricity cable.

12b. A farmhand was killed when his chainsaw cut through it.

The sentence construction (12b) can be grammatically accepted because the pronoun can replace the direct object noun phrase 11,000-volt electricity cable. This proves that the phrasal verb cut through is an inseparable phrasal verb.

The phrasal verb cut through in sentence (12) includes a dynamic verb type of activity verb type. This verb shows actions and events with subjects acting as agents semantically. In sentence (15), the noun phrase $A$ farmhand acts as the agent that carries out the 'cutting' activity.

\section{Flick through}

Syntactically, the sentence below has the following structure:

13. We flick through a few of them.

Based on the syntactic structure, sentence (13) has a phrasal verb flick through which is followed by an object in the form of the noun phrase a few of them. As the characteristics of English verbs in general, the form of phrasal verb flick through in the sentence above is a transitive phrasal verb because it has a direct object that follows it. 
https://berumpun.ubb.ac.id/index.php/BRP

Based on the type, the phrasal verbs of the flick through are categorized into the inseparable type of transitive phrasal verbs. This is proven by the following tests: Insertion of noun phrases

In the type of inseparable phrasal verb, the noun phrase which is the direct object of the phrasal verb cannot be inserted between the verb and the particle. This is seen in the following sentence construction:

13. We flick through a few of them.

'We glance at some of them.'

13a. * We flick a few of them through.

* We glance at some of them through.

Sentence (13a) shows that the verb flick is a type of intransitive verb that cannot be followed by a direct object in the form of noun phrases. Therefore, the phrasal verbs of flick through are inseparable with the insertion of noun phrases between verb flick and particle through.

Restoration with pronouns

Tests by restoring noun phrases with pronouns prove that a phrasal verb is inseparable. In this test noun phrases that function as objects are immediately replaced by pronouns of similar objects and put them at the end of sentences.

In sentence (13), the noun phrase a few of them, which functions as a direct object for the phrasal verbs of the flick through, is replaced with the pronoun it, becoming:

13. We flick through a few of them.

'We glance at some of them.'

13b. We flick through it.

'We glance at some of them.'

The sentence construction (13b) can be grammatically accepted because the pronoun can replace the direct object of the noun phrase a few of them. This proves that the phrasal verb of the flick through is a type of inseparable phrasal verbs.

The phrasal verb flick through in sentence (13) belongs to a group of dynamic verbs of activity verb type. This verb shows actions and events with subjects acting as agents semantically. In sentence (13), pronouns we act as agents who carry out 'glancing' activities.

\section{Get through}

Based on the syntactic structure, sentence (14) has a phrasal verb get through, followed by an object in the form of my friend's noun phrase. Like the characteristics 
https://berumpun.ubb.ac.id/index.php/BRP

of English verbs in general, the form of the phrasal verbs get through in the sentence above is a transitive phrasal verb because it has a direct object that follows $i t$.

14. I can't get through to my friend.

Based on its type, the phrasal verb get through is categorized into the inseparable transitive phrasal verb type. This is proven by the following tests:

Insertion of noun phrases

In the type of inseparable phrasal verb, the noun phrase which is the direct object of the phrasal verb cannot be inserted between the verb and the particle. This is seen in the following sentence construction:

14. I can't get through to my friend.

'I was unable to contact my friend.'

14a. * I can't get to my friend through.

Sentence (14a) shows that the verb get is a type of intransitive verb that cannot be followed by a direct object in the form of noun phrases. Therefore, phrasal verbs get through are inseparable from the insertion of noun phrases between verb get and particle through.

\section{Restoration with pronouns}

Tests by restoring noun phrases with pronouns prove that a phrasal verb is inseparable. In this test noun phrases that function as objects are immediately replaced by pronouns of similar objects and put them at the end of sentences.

In sentence (14), the noun phrase my friend which functions as a direct object for the verb phrasal verb get through is replaced by the pronoun her, becoming:

14. I can't get through to my friend.

'I was unable to contact my friend.'

14b. I can't get through to her.

'I was unable to contact my friend.'

The sentence construction (14b) can be grammatically accepted because the pronoun can replace the direct object of the noun phrase my friend. This proves that the phrasal verb get through is a type of inseparable phrasal verb.

The phrasal verb get through in sentence (14) belongs to a dynamic group of activity verbs. This verb shows actions and events with subjects acting as agents semantically. In sentence (14), my friend's pronoun acts as an agent that engages in 'contacting' activities. Based on its syntactic behavior, the construction of dynamic inseparable transitive phrasal verbs can be assessed as follows: 


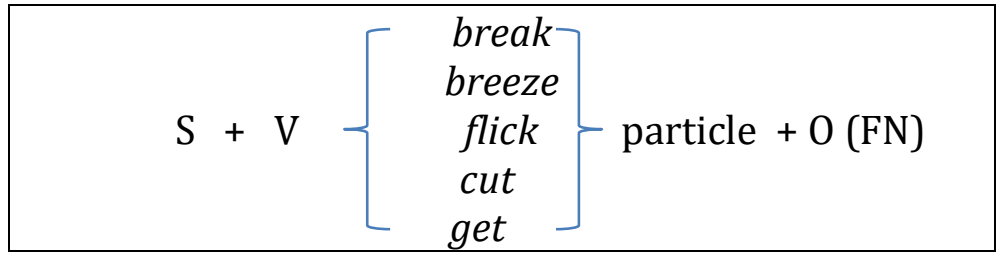

\section{CONCLUSION}

From the results of research on phrasal verbs, it can be concluded as follows:

Types of phrasal verbs found in sentences are broadly divided into two types, namely separable transitive phrasal verbs and inseparable transitive phrasal verbs. The two types of phrasal verbs are classified again based on the type of dynamic verb so that the separable and inseparable transitive phrasal verbs dynamic is obtained.

Separable Transitive dynamic phrasal verbs indicate the existence of an activity carried out by the subject of the sentence. Separable transitive phrasal verbs dynamic are found in activity verb type data such as carry through, cut through, push through, read through, and talk through. Inseparable transitive phrasal verbs dynamic indicates the existence of an activity carried out by the subject of the sentence. Inseparable transitive phrasal verbs dynamic based on data found five activity verbs such as break through 'overcome', breeze through 'accelerate', cut through 'cut through,' glance through 'flick through' and get through 'contact's.

\section{REFERENCES}

Anggraeni, D. 2019. Intransitive Phrasal Verbs with Particle Through in British National Corpus. Lire Journal. Journal of Linguistics and Literature Vo; 3. No 1 March 2019. P. 22-34.

Biber, D. et. al. 2009. Longman Grammar of Spoken and Written English. London: Pearson Education Limited Edinburgh Gate.

Djajasudarma, T. F. 2016. Metode Linguistik. Ancangan Metode Penelitian dan Kajian. Bandung: PT. ERESCO IKAPI Member.

2012. Semantik 1 Makna Leksikal dan Gramatikal. Bandung: PT Refika Aditama.

Goldberg, A. E. 2005. Argument realization: The role of constructions, lexical semantics and discourse factors. In Östman, Jan-Ola and Mirjam Fried, eds. Construction grammars: Cognitive grounding and theoretical extensions. Amsterdam/Philadelphia: John Benjamins Publishing Company. 17-43. 
2006. Constructions at work: the nature of generalization in language.

Oxford: Oxford University Press. 99

Gorlach, M. 2004. Phrasal constructions and resultativeness in English. Amsterdam: John Benjamins Publishing Company.

Greenbaum, Sydney \& Nelson, Gerald. 2002. An Introduction to English Grammar Second Edition. Great Britain. Pearson Education Limited.

Klammer, Thomas P.et.al. 2000. Analyzing English Grammar Third Edition. London: Allyn \& Bacon. A Pearson Education.

Kridalaksana, H. 2002. Struktur, Kategori, dan Fungsi dalam Teori Sintaksis. Jakarta: Universitas Katolik Indonesia Atma Jaya.

Jacobs, R. A. \& Rosenbaum, P. S. (1993). English transformational grammar. Waltham, Massachusetts: Blaisdell Publishing Company.

Jackendoff, R. 2010. Meaning and the lexicon: the parallel architecture 1975- 2010. Oxford: Oxford University Press.

Lester, M. 2009. English Grammar Drill, USA: The McGraw - Hill Companies, Inc.

Leech, G. 2003. Semantik. Partana, Paina (terjemahan). Yogyakarta: Pustaka Pelajar.

Leech, G. \& Short, M. 2007. Style in Fiction: A Linguistic Introduction to English Fictional Prose. United Kingdom: Pearson Education Limited.

Leech, G. \& Svartvik, J. 2013. A Communicative Grammar of English. Inggris: Taylor \& Francis Group, UK.

Lackman, K. 2012. Teaching Phrasal Verbs 'Activities Promoting A Strategic Approach'. Ken Lackman \& Associates: Educational consultans.

McCarthy, M. \& Felicity 0. 2007. English Phrasal Verbs in Use. USA: Cambridge University Press.

Machonis, P. A. 2009. 'Compositional phrasal verbs with up: direction, aspect, intensity.' dalam Lingvisticae Investigationes. June 2009, Vol.32 Issue 2, p253-264. 12p. 2 Charts.

Murcia-Celce, M. \& Larsen-Freeman, D. 2016. The Grammar Book. USA: Heinle\&Heinle Publishers.

Olson, Anna L. 2013. Constructions and Result: English Phrasal Verbs as Analyzed in Construction Grammar. Trinity Western University.

Pateda, M. 2010. Semantik Leksikal. Jakarta: Rineka Cipta. 
https://berumpun.ubb.ac.id/index.php/BRP

Rodríguez - Puente, P. 2012. The Development of Non - compositional Meanings in Phrasal Verbs: A Corpus - based Study. English Studies. Feb2012, Vol. 93 Issue 1, p71-90. 20p. 3 Graphs.

Riguel, E. 2014. Phrasal Verbs:Usage and Acquisition. PhD Student, University of Sorbonne Nouvelle-Paris 3, France. June 2014, Vol 1, No. 2 (Athens Journal of Philology).

Sobarna, C. 2012. Preposisi Bahasa Sunda. Bandung: Syabas Books.

Sudaryanto. 2015. Metode dan Aneka Teknik Analisis Bahasa Pengantar Penelitian Wahana Kebudayaan Secara Linguistis. Yogyakarta: Sanata Dharma University Press.

Soemantri, Y. S. 2010. Verba berpreposisi to bahasa Inggris: Kajian Sintaktis dan semantis. (Disertasi) Bandung: Universitas Padjadjaran.

Sadeqkouhestani, A. \& Rahimy, R. 2013. An Investigation into the Effect of Teaching Phrasal Verbs on the Learners Knowledge of Grammatical Patterns'. dalam Modern Journal of Language Teaching Methods. June 2013. Vol. 3, No. 2.

Wyatt, R. 2006. Check Your English Vocabulary for Verba phrasal and Idioms. London: A \& C Black. 